\title{
Comparative Analysis of the Treatment of Chronic Antipsychotic Drugs on Epileptic Susceptibility in Genetically Epilepsy-prone Rats
}

\author{
Rita Citraro • Antonio Leo • Rossana Aiello • Michela Pugliese • \\ Emilio Russo • Giovambattista De Sarro
}

Published online: 18 November 2014

(C) The American Society for Experimental NeuroTherapeutics, Inc. 2014

\begin{abstract}
Antipsychotic drugs (APs) are of great benefit in several psychiatric disorders, but they can be associated with various adverse effects, including seizures. To investigate the effects of chronic antipsychotic treatment on seizure susceptibility in genetically epilepsy-prone rats, some APs were administered for 7 weeks, and seizure susceptibility (audiogenic seizures) was evaluated once a week during treatment and for 5 weeks after drug withdrawal. Furthermore, acute and subchronic (5-day treatment) effects were also measured. Rats received haloperidol $(0.2-1.0 \mathrm{mg} / \mathrm{kg})$, clozapine $(1-5 \mathrm{mg} / \mathrm{kg})$, risperidone $(0.03-0.50 \mathrm{mg} / \mathrm{kg})$, quetiapine $(2-10 \mathrm{mg} / \mathrm{kg})$, aripriprazole $(0.2-1.0 \mathrm{mg} / \mathrm{kg})$, and olanzapine $(0.13-$ $0.66 \mathrm{mg} / \mathrm{kg}$ ), and tested according to treatment duration. Acute administration of APs had no effect on seizures, whereas, after regular treatment, aripiprazole reduced seizure severity; haloperidol had no effects and all other APs increased seizure severity. In chronically treated rats, clozapine showed the most marked proconvulsant effects, followed by risperidone and olanzapine. Quetiapine and haloperidol had only modest effects, and aripiprazole was anticonvulsant. Finally, the proconvulsant effects lasted at least 2-3 weeks after treatment suspension; for aripiprazole, a proconvulsant rebound effect was observed. Taken together, these results indicate and confirm that APs might have the potential to increase the severity of audiogenic seizures but that aripiprazole may exert anticonvulsant effects. The use of APs in patients, particularly
\end{abstract}

R. Citraro $\cdot$ A. Leo $\cdot$ R. Aiello $\cdot$ E. Russo $(\varangle) \cdot$ G. De Sarro Science of Health Department, School of Medicine, University "Magna Graecia" of Catanzaro, Viale Europa - Germaneto, 88100 Catanzaro, Italy

e-mail: erusso@unicz.it

M. Pugliese

Department of Veterinary Science, University of Messina, Messina, Italy in patients with epilepsy, should be monitored for seizure occurrence, including during the time after cessation of therapy. Further studies will determine whether aripiprazole really has a potential as an anticonvulsant drug and might also be clinically relevant for epileptic patients with psychiatric comorbidities.

Keywords Audiogenic seizures · Clozapine · Aripiprazole · Olanzapine $\cdot$ Quetiapine $\cdot$ Haloperidol

\section{Introduction}

Antipsychotic drugs (APs) can be of great benefit in several psychiatric disorders, including schizophrenia and bipolar disorder, although they are all associated with different adverse effects such as oversedation, neuroleptic malignant syndrome, extrapyramidal symptoms, tardive dyskinesia, anticholinergic symptoms, and seizures [1-6]. Most neuroleptics can lower seizure threshold and increase the chance of seizure occurrence [3, 7-9]. Furthermore, a strong link exists between epilepsy and psychiatric disorders; it is known that such comorbidity exists; many epileptic patients have psychiatric disorders; and, conversely, depressed patients have a higher risk of becoming epileptic [10-14].

Chlorpromazine, a first-generation AP, appears to be associated with the greatest risk of seizure induction; in contrast, haloperidol, fluphenazine, pimozide, and trifluoperazine are associated with a lower risk of seizures. Clozapine and olanzapine are the second-generation antipsychotics most frequently associated with seizures, while risperidone appears to have a relatively low seizure induction risk [9]. Previous reports indicated that, among the conventional APs, the clinical incidence of seizures during treatment with chlorpromazine was $1.25 \%$ (10/800 patients) [15], whereas haloperidol rarely induces clinical seizure [16]. Furthermore, the clinical 
incidence of seizures during treatment with atypical APs was $2.89 \%$ (41/1418 patients) for clozapine, $2.34 \%(28 / 1196$ patients) for zotepine, $0.88 \%$ (22/2500 patients) for olanzapine, $0.75 \%$ (18/2387 patients) for quetiapine, and $0.35 \%$ (9/2607 patients) for risperidone [3, 7-9]. However, the above data are largely based on studies that were not adequately controlled [3, 7-9, 15, 16].

Some years ago, Kumlien and Lundberg [17] have surveyed reports of suspected seizures from 1968 to February 2006 and have reported cases of adverse drug reactions for each psychotropic drug. Of a total of 71,471 convulsive events, the APs most frequently associated with convulsive adverse drug reactions were clozapine (9.00\%), chlorprothiexene (8.89\%), and quetiapine (5.90\%). However, fluphenazine, haloperidol, pimozide, and risperidone exhibited a relatively low risk $[17,18]$.

Chronic treatment with clozapine has been shown to induce epileptic seizures consistent with kindling in rats [19]. Also, antipsychotic treatments during ethanol withdrawal may worsen audiogenic seizures, whereas risperidone, quetiapine, and ziprasidone are effective on audiogenic seizures during ethanol withdrawal syndrome [20]. Neither clozapine nor olanzapine treatments affected the incidence and the latency of audiogenic seizures in ethanol-dependent rats [21, 22]. Recently, we have reported that aripiprazole, a new atypical AP, was able to reduce absence seizures with positive modulatory actions on depression and anxiety in WAG/Rij rats, an animal model of epilepsy and depression comorbidity [23].

Genetically epilepsy-prone rats (GEPRs) represent an established animal model to study the pathophysiology of seizures and to screen potential new antiepileptic drugs [24-31]. In this strain, epilepsy is genetically determined, even though the exact mechanisms underlying the development of the disorder remain incompletely understood [24, 27]. A nonspecific propensity for generalized seizures, regardless of the eliciting stimuli, enhances the value of this strain of rats as a model in the study of gene-linked generalized epilepsy. GEPRs are a useful model of convulsive epilepsy; the rats exhibit generalized tonic-clonic seizures in response to certain stimuli (i.e., sound and hyperthermia), with a lower threshold and more intense seizure response to a given stimulus (i.e., electrical or chemical) than other strains [24, 26, 30, 32]. Various neurotransmitters have been involved in the genesis of seizures in this animal model, and particular attention has been focused on both gamma-aminobutyric acid (GABA) and glutamate [24, 33, 34]. Additionally, drugs decreasing noradrenergic or serotonergic transmission increase convulsion intensity in GEPRs, while drugs increasing serotonergic or noradrenergic function decrease convulsion intensity [27, 35-37]. Finally, noradrenergic deficiencies exist in GEPRs that have experienced multiple sound-induced seizures, as well as in GEPRs that have been protected from seizureprovoking stimuli $[27,38]$.
There is a lack of information about the effects of the exposure of chronic APs on genetic animal models of epilepsy. The aim of the present study was to investigate and compare possible AP-induced alterations in the development of seizure susceptibility in a genetic rat model of audiogenic (convulsive) seizures (GEPRs).

\section{Methods}

Animals

GEPRs, a strain derived from Sprague-Dawley (SD) rats, were selected in our breeding stock (Pharmacology Unit, Department of Health Sciences, University of Catanzaro, Italy) from a colony originally supplied by Professor B.S. Meldrum (University of London, UK). SD rats of 1 month of age were purchased from Harlan Italy (Correzzana, Milan, Italy). In order to select the rats for experiments, only male GEPRs were tested 3 times at weekly intervals between 6 and 8 weeks of age, and only animals that showed a stage 2-3 (GEPR-3s) or 8-9 (GEPR-9s) audiogenic seizure in all 3 exposures to sound stimulation were divided into respective groups and used for these experiments (for details, see the audiogenic stimulation protocol paragraph and Table 1) [39]. The GEPRs that showed no audiogenic seizures in all 3 exposures to sound stimulation were considered as group GEPR-0. In addition, SD rats were tested 3 times at weekly intervals between 6 and 8 weeks of age in order to exclude responsive animals.

Only male rats of all strains and subgroups were used and housed 3 or 4 per cage under stable conditions of humidity ( 60 $\pm 5 \%)$ and temperature $\left(21 \pm 2{ }^{\circ} \mathrm{C}\right)$, and were kept under a reversed light/dark (12/12 h) cycle (light on at 19:00). The latter were given free access to food (Harlan Teklad rodent diet) and tap water until the time of experiments. Each experimental group in this protocol included 8 rats. Procedures involving animals and their care were conducted in conformity with the international and national law and policies (European Union Directive 2010/63/EU for animal experiments; Animal Research: Reporting of In Vivo Experiments guidelines; and the Basel declaration, including the 3R concept). All efforts were made to minimize animal suffering and to reduce the number of animals used.

\section{Acute Treatment Procedure}

For intraperitoneal (i.p.) administration, haloperidol and clozapine (Sigma-Aldrich, Milan, Italy), risperidone (Janssen Cilag, Milan, Italy), quetiapine (Astra Zeneca, Milan, Italy), and (Abilify, Otsuka Pharmaceutical Italy S.r.l., Milan, Italy) were dissolved in $0.1 \%$ acetic acid, while olanzapine (Eli Lilly, Florence, Italy) and ketotifen fumarate (Biofutura 
Table 1 Experimental protocol scheme

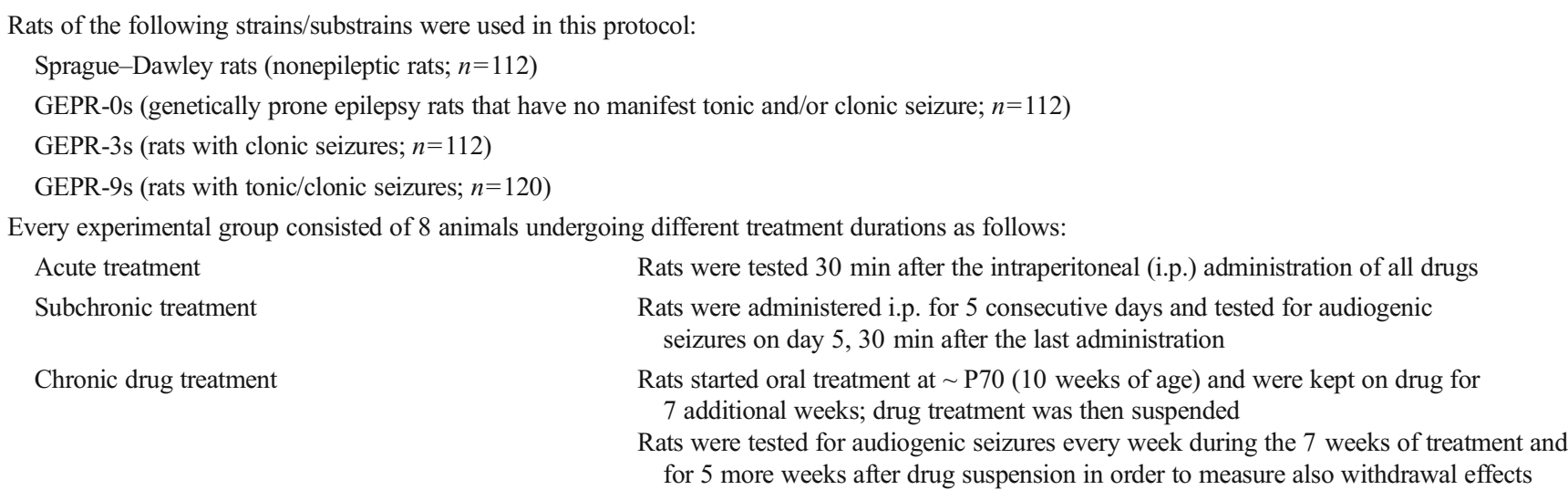

Drugs used were tested at the following doses:

haloperidol $(0.2$ and $1.0 \mathrm{mg} / \mathrm{kg})$

clozapine (1 and $5 \mathrm{mg} / \mathrm{kg}$ )

risperidone $(0.13$ and $0.66 \mathrm{mg} / \mathrm{kg})$

quetiapine (2 and $10 \mathrm{mg} / \mathrm{kg}$ )

aripriprazole $(0.2,0.5$, and $1.0 \mathrm{mg} / \mathrm{kg})$

olanzapine $(0.13$ and $0.66 \mathrm{mg} / \mathrm{kg})$

ketotifen fumarate $(3 \mathrm{mg} / \mathrm{kg})$

All drugs at all doses were tested in all experimental paradigms with 8 animals in every drug/dose group plus a vehicle control group for every rat strain/ substrain

Farmaceutica, Rome, Italy) were dissolved in sterile saline. Haloperidol ( 0.2 and $1.0 \mathrm{mg} / \mathrm{kg})$, clozapine (1 and $5 \mathrm{mg} / \mathrm{kg})$, risperidone $(0.03,0.13$, and $0.50 \mathrm{mg} / \mathrm{kg})$, quetiapine (2 and $10 \mathrm{mg} / \mathrm{kg})$, aripiprazole $(0.2,0.5$, and $1.0 \mathrm{mg} / \mathrm{kg})$, olanzapine $(0.13$ and $0.66 \mathrm{mg} / \mathrm{kg})$, and ketotifen fumarate $(3 \mathrm{mg} / \mathrm{kg}$ ) were injected i.p. for acute treatment at a volume of $1 \mathrm{ml} / \mathrm{kg}$ body weight. Control animals received equivalent volumes of vehicle at the respective times before the test. Rats were always tested 30 min after drugs or vehicle administration (see Table 1 for experimental scheme). Doses of the drugs were selected from our preliminary experiments and previous studies [20, 40-42]. As higher doses of most of antipsychotics and other drugs used in our preliminary studies and in previous reports caused sedation and/or impairment of motor coordination [43], such doses were not used.

Chronic and Sub-chronic Treatment Procedure

For chronic or subchronic treatment, all drugs were orally administered at the doses above described (see "Acute Treatment Procedure" section) dissolving adequate samples of each drug in $120 \mathrm{ml}$ of drinking water (e.g., clozapine $1 \mathrm{mg} / \mathrm{kg}$ : $1 \mathrm{mg}$ in $120 \mathrm{ml}$ of water). Dosage was calculated on the basis of the knowledge that rats drink, on average, 10$12 \mathrm{ml} / 100 \mathrm{~g} /$ day; the volume drunk was also checked weekly [44]. Drug solutions were freshly prepared, replaced 2 or 3 times a week, and bottles were wrapped in silver foil to exclude light $[45,46]$.

\section{Chronic drug treatment protocol}

Rats ( $n=8$ animals for each group and each dose) started treatment at $\sim$ P70 (10 weeks of age) and were kept on the drug for 7 additional weeks; treatment was then stopped and animals were normally housed for 5 more weeks in order to evaluate possible withdrawal effects.

\section{For subchronic treatment}

All animals ( $n=8$ per group) received orally administered drug for 5 consecutive days at the same doses used for chronic treatment and tested $30 \mathrm{~min}$ after the last administration. Control animals $(n=8)$ were kept under standard conditions and tested in the same time window of the corresponding treated groups (see Table 1 for experimental scheme). During this period, animals were weighed weekly every Monday between 9:00 and 11:00. Furthermore, particular attention was paid to the possible appearance of any obvious drug induced side-effects [47].

\section{Audiogenic Stimulation Protocol}

At 10 weeks of age, rats of every GEPRs subgroup (GEPR-0s, GEPR-3s, and GEPR-9s) were randomly assigned to a single drug dose ( $n=8$ for each dose). Similarly, SD rats were assigned to each drug. Rats were then weekly tested for 
audiogenic seizures by exposing them to a mixed frequency sound of $12-16 \mathrm{kHz}, 109 \mathrm{~dB}$ intensity under a hemispheric Plexiglas dome (diameter of $58 \mathrm{~cm}$ ). Individual animals were placed into the dome box for habituation at least $2 \mathrm{~min}$ before sound stimulation. Auditory stimulation was applied for $1 \mathrm{~min}$. A full seizure response consisted of 1 or 2 running phases, followed by a convulsion (clonus of forelimbs, hindlimbs, head, pinnae, vibrissae, and tail) and tonic extension to give a score of 9 [48]. In particular, the audiogenic seizure response was assessed on the following scale, as previously described $[27,39]$ : $0=$ no response; $1=$ running only; $2=2$ running phases, followed by a clonic convulsion (clonus of forelimbs, hindlimbs, head, pinnae, vibrissae, and tail); $3=1$ running phase, followed by a clonic convulsion (clonus of forelimbs, hindlimbs, head, pinnae, vibrissae, and tail); $4=2$ running phases followed by tonus of neck, trunk, and forelimb, and hindlimb clonus; $5=1$ running phase followed by tonus of neck, trunk, and forelimb, and hindlimb clonus; $6=2$ running phases followed by nearly complete tonic extension except hindfeet; $7=1$ running phase followed by nearly complete tonic extension except hindfeet; $8=2$ running phases followed by complete tonic extension; and $9=1$ running phase followed by complete tonic extension. The maximum response was recorded for each animal.

\section{Statistical Analysis}

All statistical procedures were performed using SPSS 15.0.0 (IBM, Armonk, NY, USA). Comparison between acutely injected and subchronically treated groups of rats was accomplished using one-way analysis of variance followed by Dunnett's post hoc analysis comparing every drug dose group with its own control rat group; for example clozapine $(1 \mathrm{mg} / \mathrm{kg})$ GEPR-3s group versus control GEPR-3s group. Data from chronic treatments were first grouped by strain subgroups (i.e., SD, GEPR-0s, GEPR-3s, and GEPR-9s) and then divided by week of treatment. Such divided data were then compared by one-way analysis of variance followed by Tukey's post hoc test being treatment the only variable. For each GEPR, maximum response to auditory stimuli was recorded. A $p$-value $\leq 0.05$ was considered significant for every test. Considering that a large number of comparisons might, in theory, engender false positive results (type 1 errors) in pharmacological research, we have reduced, at the minimum, the number of comparisons in our statistics. Furthermore, it is unlikely that false positive results are reported in our study for 2 reasons: 1) we use a relatively small sample size of mice - a situation that minimizes the occurrence of false positive findings (it is well known that $p$-value associated with a fixed effect is reduced as the sample size increases and vice versa); 2) the biological plausibility and the statistical consistency of study results [49].

\section{Results}

Effects of Acute Intraperitoneal Administration of Antipsychotic Drugs on Audiogenic Seizures

In order to evaluate the possible effects of acute administration of APs on audiogenic seizures in GEPRs, we used 3 subgroups of rats: the first group had no seizures (GEPR-0); the second group manifested the clonic component only (GEPR-3); and the third group comprised rats who had a full seizure response that culminated in a complete tonic extension (GEPR-9). These responses were identified in the 3 previous screening tests carried out between 6 and 8 weeks of the rat's life.

Single i.p. administration of haloperidol $(0.2$ and $1.0 \mathrm{mg} / \mathrm{kg}$ ), clozapine $(1$ and $5 \mathrm{mg} / \mathrm{kg})$, risperidone $(0.03$, 0.13 , and $0.50 \mathrm{mg} / \mathrm{kg}$ ), quetiapine ( 2 and $10 \mathrm{mg} / \mathrm{kg}$ ), aripiprazole $(0.2,0.5$, and $1.0 \mathrm{mg} / \mathrm{kg})$, or olanzapine $(0.13$ and $0.66 \mathrm{mg} / \mathrm{kg}$ ) induced no significant changes in seizure score severity in GEPR-9s, GEPR-3s and GEPR-0s (data not shown).

No significant effect on the latency time from audiogenic stimulus, onset to the initiation of wild running or clonus in GEPR-3s, and tonus in GEPR-9s after systemic administration of the above-reported APs was observed (data not shown). All control animals (SD rats or GEPRs vehicletreated) did not manifest significant changes in audiogenic seizures score following auditory stimulation, as previously described [50, 51].

\section{Effects of Daily Antipsychotic Treatment on Severity of Audiogenic Seizures}

Oral administration of haloperidol $(0.2$ and $1.0 \mathrm{mg} / \mathrm{kg} / \mathrm{day})$, clozapine ( 1 and $5 \mathrm{mg} / \mathrm{kg} /$ day), risperidone $(0.03,0.13$, and $0.50 \mathrm{mg} / \mathrm{kg} / \mathrm{day}$ ), quetiapine ( 2 and $10 \mathrm{mg} / \mathrm{kg} / \mathrm{day}$ ), aripiprazole $(0.2,0.5$, and $1.0 \mathrm{mg} / \mathrm{kg} / \mathrm{day})$, and olanzapine $(0.13$ and $0.66 \mathrm{mg} / \mathrm{kg} / \mathrm{day})$ was carried out for 5 days, and each group of rats and its vehicle control group received auditory stimulus once after 5 days.

The oral subchronic treatment with APs for 5 days in SD rats did not induce the appearance of audiogenic seizures following auditory stimulation in comparison with the SD control group, as previously described (data not shown) [26, 51, 52]. In GEPR-0s, haloperidol, quetiapine, and aripiprazole did not induce any change compared with the control GEPR-0 group at all doses used, whereas clozapine, risperidone, and olanzapine were able to induce the appearance of clonic phase of the audiogenic seizures (score 2-3) at the highest doses used (Fig. 1a).

In GEPR-3s, subchronic treatment with aripiprazole reduced the incidence of clonus at a dose of $1 \mathrm{mg} / \mathrm{kg}$, while haloperidol, at all doses used, induced no significant changes 
Fig. 1 Effects of subchronic treatment with antipsychotic drugs on seizure severity in genetically epilepsy-prone rats (GEPRs). (a) Seizure score in GEPR-0s not displaying seizure in control conditions; (b) seizure score in GEPR-3s only displaying clonic phase in control conditions. Doses reported were the highest used in the study (haloperidol= $1 \mathrm{mg} / \mathrm{kg}$; quetiapine $=10 \mathrm{mg} / \mathrm{kg}$; risperidone $=0.5 \mathrm{mg} / \mathrm{kg}$; aripiprazole $=1 \mathrm{mg} / \mathrm{kg}$; clozapine $=5 \mathrm{mg} / \mathrm{kg}$; olanzapine $=$ $0.66 \mathrm{mg} / \mathrm{kg}$ ). *Significantly $(p<0.05)$ different from respective controls (analysis of variance). Data are means \pm SEM ( $n=8$ for each experimental group)
A

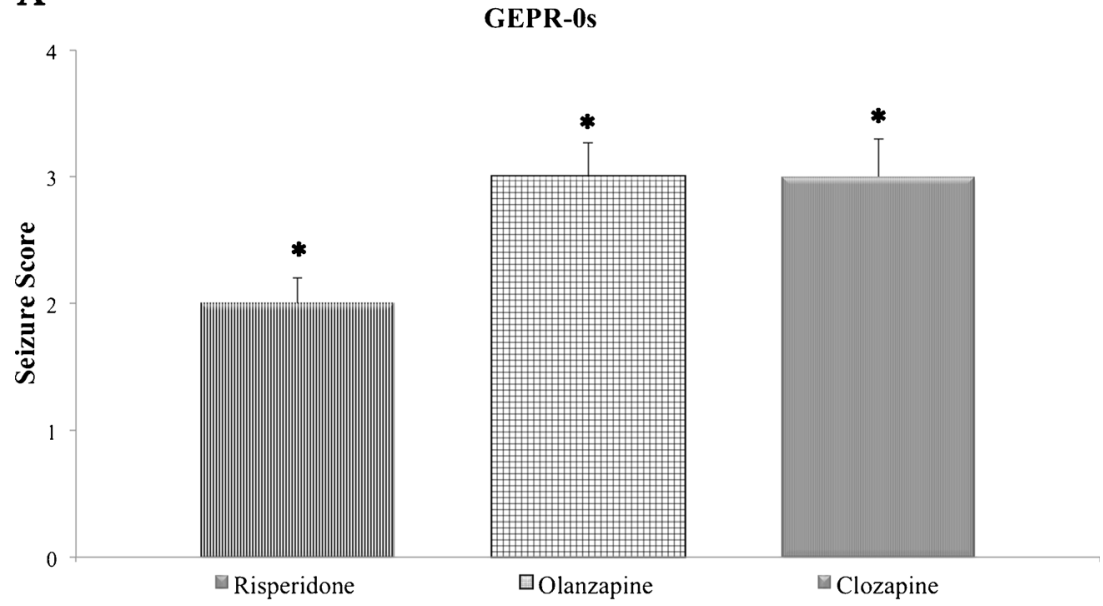

B

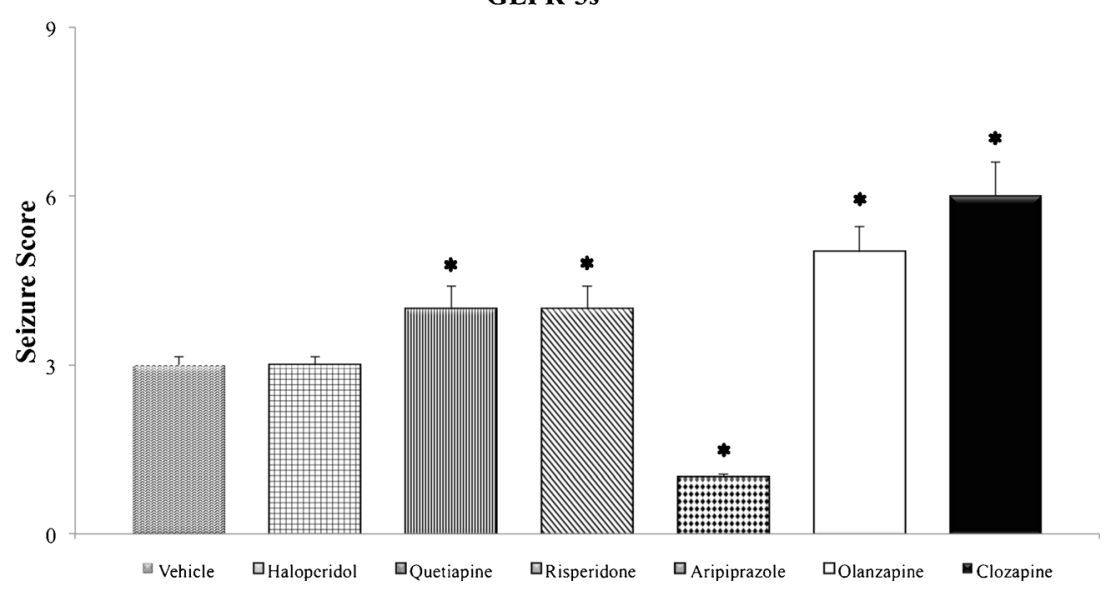

in seizure severity. In contrast, all other drugs significantly increased seizure score at the highest doses with the appearance in some cases of tonic phase in GEPR-3 rats (Fig. 1b). No significant changes in the incidence of audiogenic seizures after 5 days of treatment with APs were observed in GEPR-9s, with the exception of aripiprazole, which was able to reduce significantly the incidence and severity of seizures.

Effects of Chronic AP Treatment on Severity of Audiogenic Seizures

Chronic treatment in all groups and for every drug did not have any effect on rat weight (data not shown). In GEPR-0s, chronic administration of clozapine, risperidone, and olanzapine, at the highest doses, was able to induce the appearance of clonus after the first week of treatment, and significantly increased seizure score severity $(p<0.05)$, reaching a peak between the sixth and seventh week of treatment (Fig. 2). The effects of all low doses of antipsychotics are not reported as no marked changes in seizure score were observed. Chronic treatment with haloperidol was able to induce the appearance of clonus only on the last (week 7) week of treatment, whereas there were no significant changes on onset of audiogenic seizures with quetiapine and aripiprazole (Fig. 2).

Repeated treatment with clozapine, risperidone, quetiapine, and olanzapine caused a significant $(p<0.05)$ increase in audiogenic seizure severity after the first week in GEPR-3s (Fig. 3a-c); this was maintained at least up to 3 weeks after drug cessation. In particular, the highest doses of these APs induced a significant increase in seizure score severity (up to 5-7) in GEPR-3s between weeks 5 and 7 of treatment. Haloperidol, at a dose of $1 \mathrm{mg} / \mathrm{kg}$, produced a significant worsening $(p<0.05)$ of audiogenic seizure score, inducing the appearance of tonic phase (overall score 4-5) only between weeks 5 and 7 in GEPR-3s (Fig. 3a). In contrast, chronic treatment with aripiprazole $(0.5$ and $1.0 \mathrm{mg} / \mathrm{kg})$ produced a significant $(p<0.05)$ reduction in seizure score severity; these effects were already evident in the second week of treatment and persisted for all 7 weeks of treatment and 1 further week 


\section{GEPR-0s}

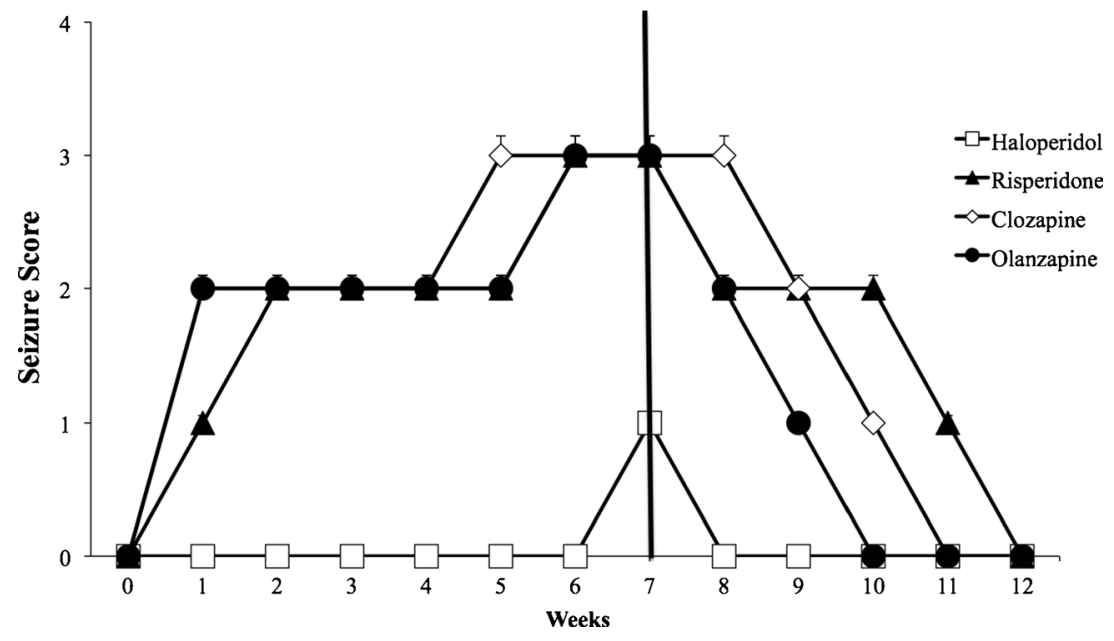

Fig. 2 Effects of chronic (7 weeks) antipsychotic treatment in genetically epilepsy-prone rats (GEPR)- $0 \mathrm{~s}$ on seizure score. Note that 5 weeks after drug suspension, the black bar indicates treatment suspension. Risperidone, clozapine, and olanzapine significantly increased seizure score severity $(p<0.05)$ after the first week of treatment, reaching a peak between weeks 6 and 7; after withdrawal, this significant increase lasted for 3, 4, and 5 weeks for olanzapine, clozapine, and risperidone, respectively. Haloperidol had significant $(p<0.05)$ effects only during week 7 of treatment. Doses reported were the highest used in the study (haloperi$\mathrm{dol}=1 \mathrm{mg} / \mathrm{kg}$; risperidone $=0.5 \mathrm{mg} / \mathrm{kg}$; clozapine $=5 \mathrm{mg} / \mathrm{kg}$; olanzapine $=$ $0.66 \mathrm{mg} / \mathrm{kg}$ ). Data are means \pm SEM ( $n=8$ for each experimental group)

score of audiogenic seizures to baseline after 2 weeks (Fig. 3a).

In addition, aripiprazole withdrawal in both GEPR-3 and GEPR-9 groups induced a complete recovery of the seizure response after 1 week of withdrawal (Figs. 3d and 4). Of note, 3 weeks after suspension, a rebound effect was observed with the appearance of tonus in some previously treated GEPR-3 rats (Fig. 3d).

Effects of Acute, Subchronic, and Chronic Ketotifen Fumarate Treatment on Severity of Audiogenic Seizures in GEPR Groups

In order to evaluate the influence of $\mathrm{H} 1$ histamine antagonism on seizure severity and use it as a comparator for the APs used (see "Discussion"), single i.p. administration of ketotifen fumarate $(3 \mathrm{mg} / \mathrm{kg})$ was carried out. Acute administration and subchronic ketotifen fumarate treatment produced no significant changes in seizure severity scores in GEPR-9s, GEPR-3s, and GEPR-0s (data not shown). Oral chronic administration of ketotifen fumarate ( $3 \mathrm{mg} / \mathrm{kg} /$ day) was carried out for 7 weeks, and rats received auditory stimuli once every week, as described above for APs. Ketotifen fumarate produced a significant increase in seizure severity score in GEPR-3s after the third week of treatment, while no significant changes in the incidence of audiogenic seizures after ketotifen fumarate administration in GEPR-9s were observed. Such changes were of minor severity compared with those observed after clozapine and some atypical antipsychotics (Fig. 5a). In GEPR-0 rats, chronic ketotifen fumarate treatment induced the appearance of clonic phase (score 3) at the week 5-6 of rats, withdrawal of quetiapine induced a return of severity 
A

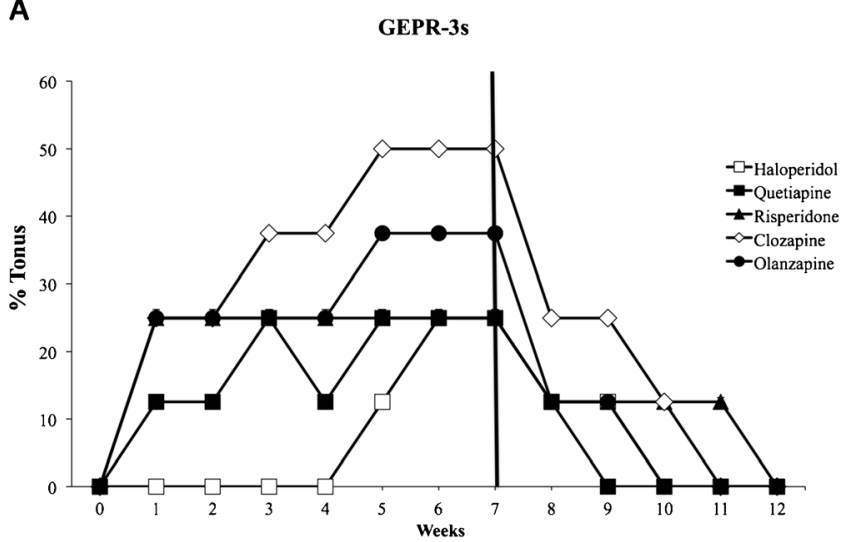

B

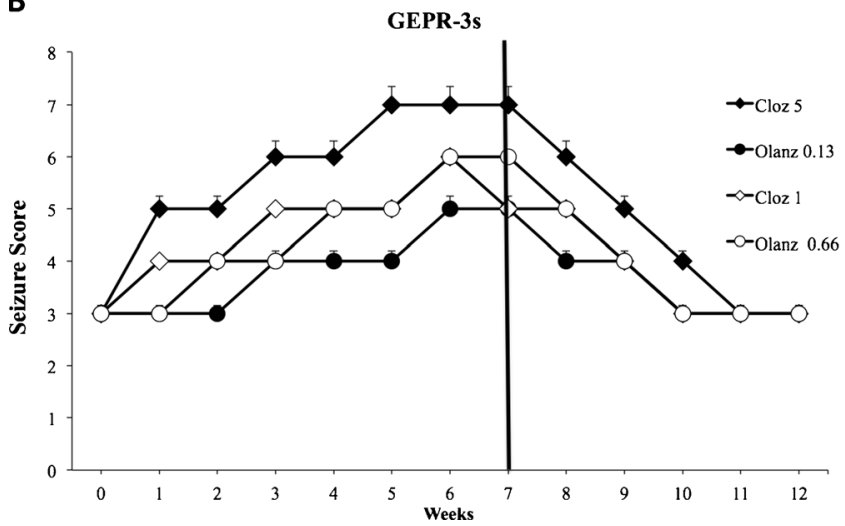

Fig. 3 Effects of chronic (7 weeks) antipsychotic treatment in genetically epilepsy-prone (GEPR)-3 s rats (clonus only) on seizure severity. Black bar indicates treatment suspension. Doses reported were the highest used in the study (haloperidol $=1 \mathrm{mg} / \mathrm{kg}$; quetiapine $=10 \mathrm{mg} / \mathrm{kg}$; risperidone $=$ $0.5 \mathrm{mg} / \mathrm{kg}$; clozapine $=5 \mathrm{mg} / \mathrm{kg}$; olanzapine $=0.66 \mathrm{mg} / \mathrm{kg}$ ), if not otherwise specified. (a) Effects of drugs on tonus incidence (\% of rats with tonus). (b) Proconvulsant effects of clozapine (Cloz) and olanzapine (Olanz) at different doses; clozapine (1 and $5 \mathrm{mg} / \mathrm{kg}$ ) significantly $(p<0.05)$ increased seizure score after the first week of treatment, returning to baseline levels 4-5 weeks after withdrawal. Olanzapine $(0.13$ and $0.66 \mathrm{mg} / \mathrm{kg})$ significantly $(p<0.05)$ increased seizure score after the second week of treatment and returned to baseline 3 weeks after withdrawal. Note the strongest proconvulsant effects of clozapine

treatment. In addition, the effects of chronic ketotifen fumarate treatment on audiogenic seizures were determined for 5 weeks after drug withdrawal (Fig. 5b). The severity of audiogenic seizures returned to control levels for both GEPR-0s and GEPR-3s after the first week.

\section{Discussion}

General Considerations on the Effect of APs on Seizures

It is generally accepted that APs can lower seizure threshold or provoke seizures $[3,8,17]$. Despite the fact that APs show efficacy in the treatment of psychosis, several differences exist

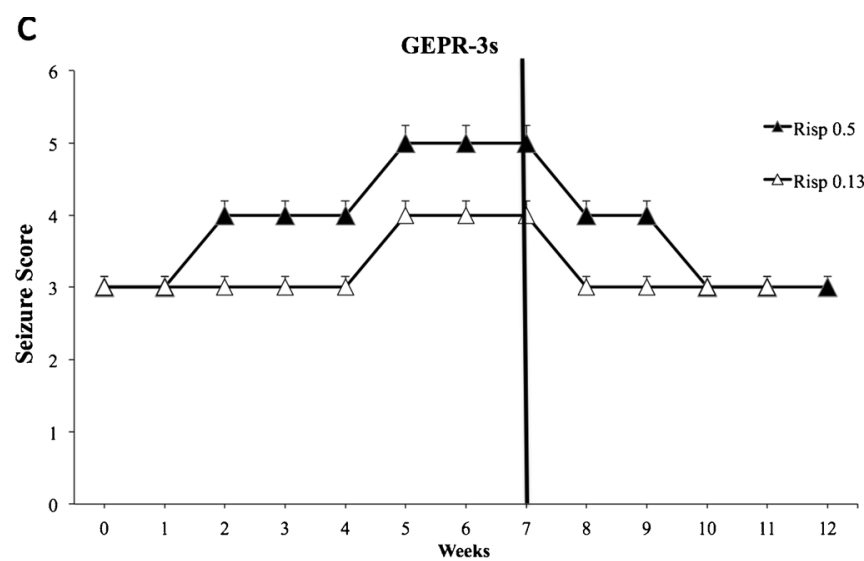

D

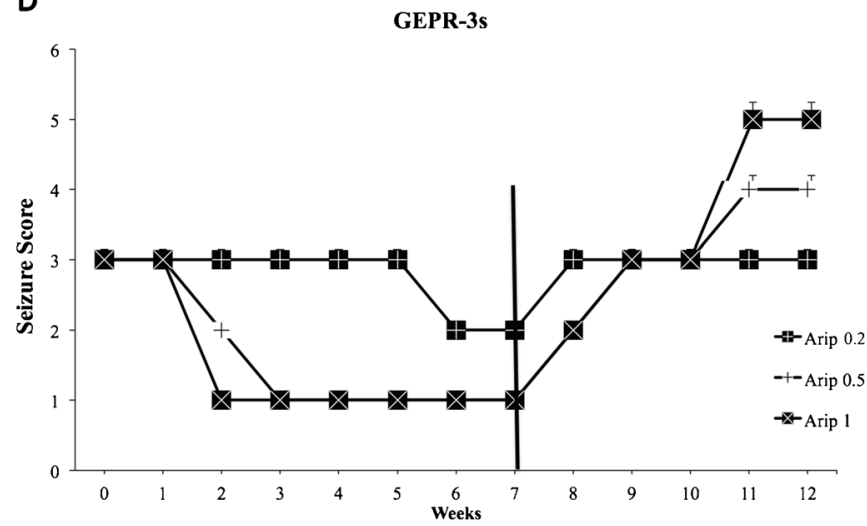

$5 \mathrm{mg} / \mathrm{kg}$. (c) Proconvulsant effects of risperidone (Risp) at different doses; risperidone $(0.5 \mathrm{mg} / \mathrm{kg})$ significantly $(p<0.05)$ increased seizure score in week 2 of treatment, returning to baseline levels 3 weeks after withdraw$\mathrm{al}$, whereas at the dose of $0.13 \mathrm{mg} / \mathrm{kg}$, risperidone significantly $(p<0.05)$ increased seizure score only between weeks 5 and 7 of treatment, with no withdrawal effects. (d) Effects of various aripiprazole (Arip) doses on seizure score; aripiprazole $(0.5$ and $1 \mathrm{mg} / \mathrm{kg})$ significantly $(p<0.05)$ reduced seizure score after the first week up to the second week after withdrawal. Aripiprazole $(0.2 \mathrm{mg} / \mathrm{kg})$ significantly $(p<0.05)$ reduced seizure score only during weeks 6 and 7 of treatment with no withdrawal effects. Note the significant $(p<0.05)$ proconvulsant effects of aripiprazole $(0.5$ and $1 \mathrm{mg} / \mathrm{kg})$ after the third week after withdrawal. Data are means $\pm \operatorname{SEM}(n=8$ for each experimental group)

in their mechanisms of action, which might differentially contribute to their effects on seizures. The present study aimed at modeling some clinical scenarios with treatment with APs: 1) rats belonging to a genetically prone epilepsy strain that have no manifest tonic and/or clonic seizure (first treatment group or GEPR-0s; people with a low seizure threshold but without previous clinical manifestation); 2) rats that have clonic seizures (second treatment group or GEPR-3s; epileptic patients); 3) rats that have manifest tonic-clonic seizures (third treatment group or GEPR-9s; epileptic patients); 4) rats that have no manifest tonic and/or clonic seizure and not belonging to genetically prone epilepsy strain currently taking their antipsychotic medication (SD control group; analogous to humans without a propensity for seizures). 
Fig. 4 Significant $(p<0.05)$ anticonvulsant effects of chronic (7 weeks) oral treatment with aripiprazole $(1 \mathrm{mg} / \mathrm{kg})$ in genetically epilepsy-prone (GEPR)-9 s from the second week without withdrawal effects. Black bar indicates treatment suspension. Data are means \pm $\operatorname{SEM}(n=8$ for each experimental group)
GEPR-9s

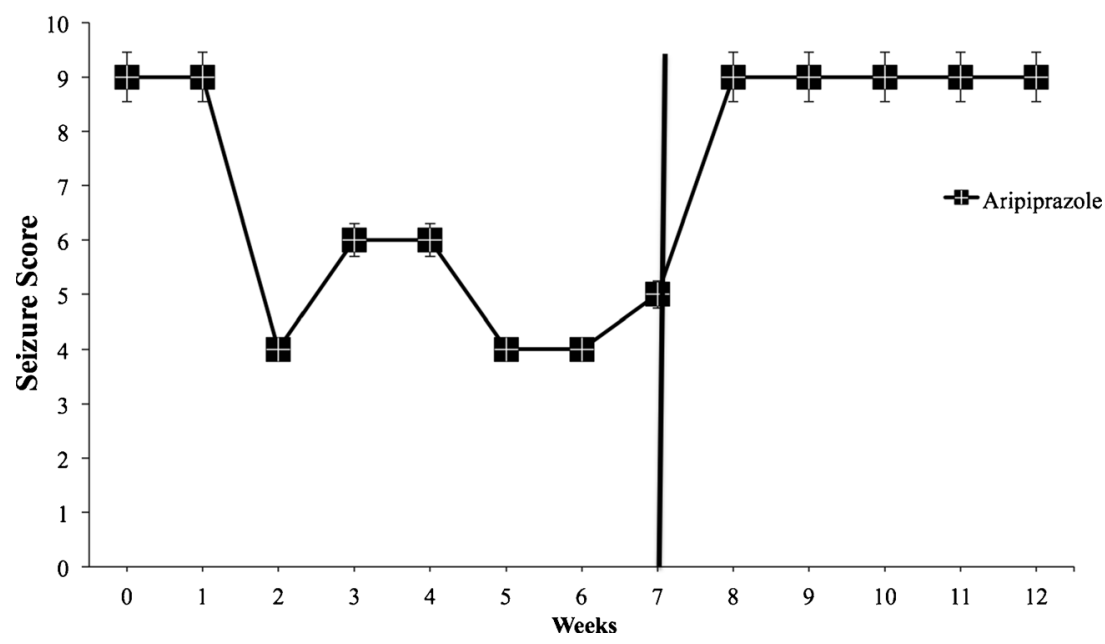

Our results demonstrate that chronic treatment with some atypical antipsychotics enhances seizure susceptibility in
GEPRs and that such increased seizure susceptibility is longlasting after drug withdrawal, indicating that APs might
Fig. 5 Effects of ketotifen fumarate $(3 \mathrm{mg} / \mathrm{kg}$; Ketotifene; H1 histaminergic antagonist) and quetiapine $(10 \mathrm{mg} / \mathrm{kg})$ on seizure scores in genetically epilepsyprone rats (GEPR)-3 s (panel a; \% of rats with tonus) and GEPR- 0 s (panel $\mathbf{b} ; \%$ of rats with clonus) rats. Black bar indicates treatment suspension. Data are means \pm SEM ( $n=8$ for each experimental group)

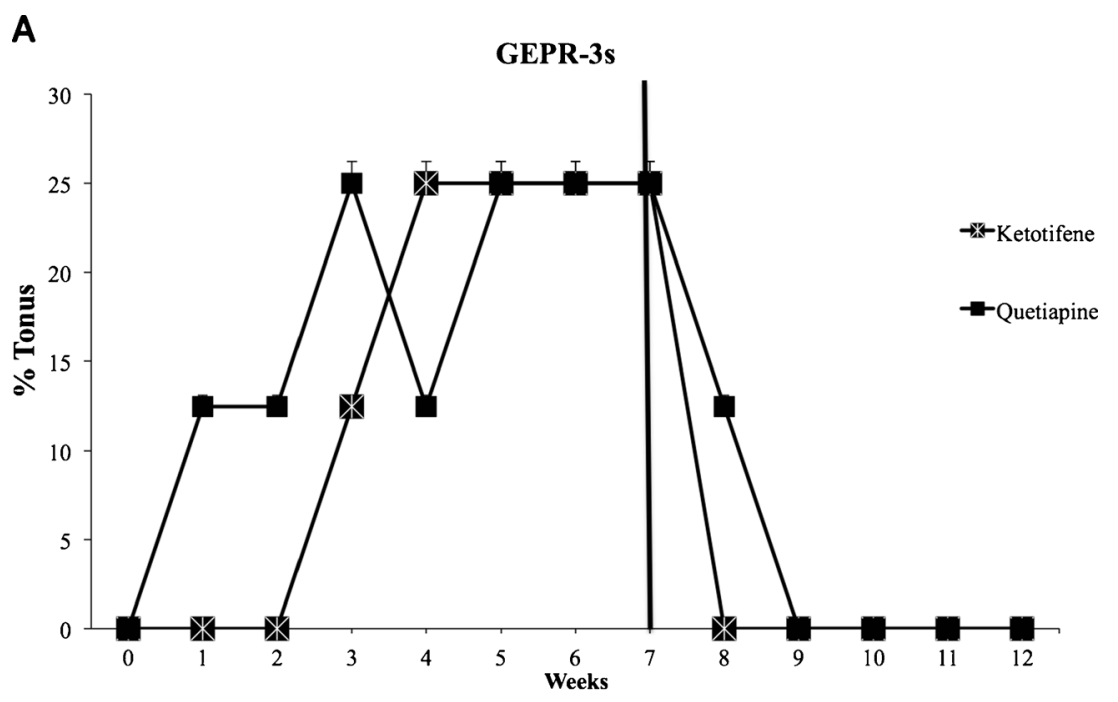

B

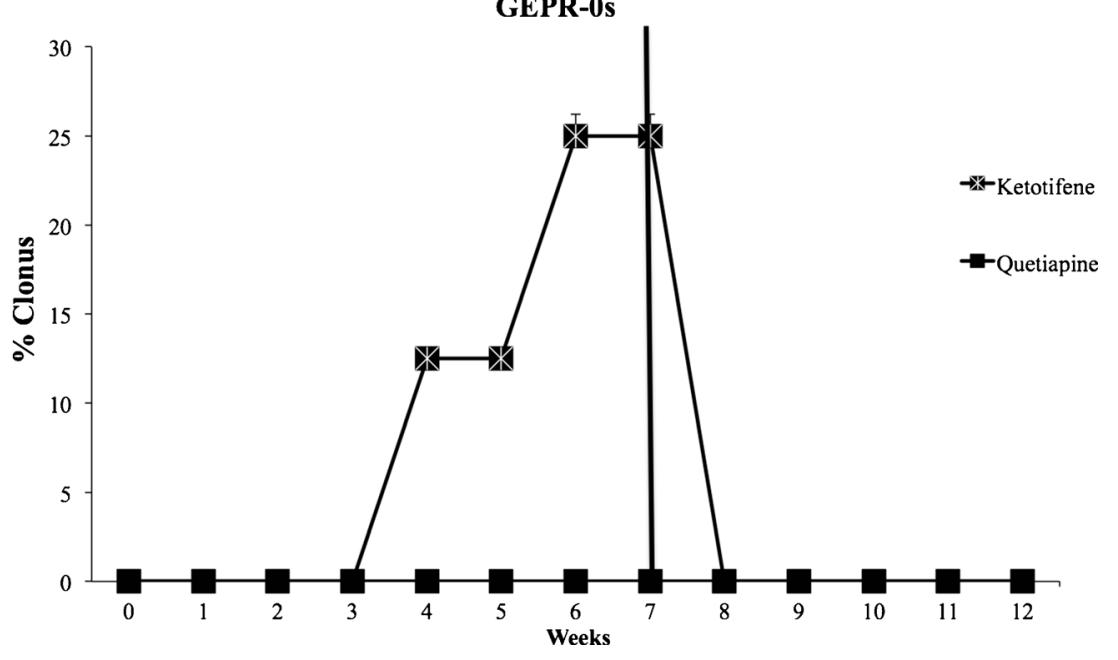


induce plastic changes in brain that could facilitate hyperexcitability. In contrast, haloperidol, a typical AP, had only minimal proconvulsant effects, while aripiprazole showed a clear anticonvulsant action although, upon withdrawal, a rebound proconvulsant effect was noted.

More specifically, no proconvulsant effects were observed in SD rats (not seizure prone). Such a result might support the absence of effects on brain excitability in rats without seizure predisposition or at least not sufficient to increase seizure susceptibility. However, it must be considered that in our experimental protocol only reflex audiogenic seizures were tested and therefore the effect of APs treatment on other seizure types (spontaneous or induced) is not known. In GEPRs: 1) haloperidol, in general, did not significantly affect audiogenic seizure occurrence with increasing severity only at the end of chronic treatment (after 5-6 weeks of administration); 2) clozapine showed the most marked proconvulsant effects; 3) risperidone and olanzapine were both proconvulsant but less so than clozapine; 4) quetiapine showed only modest proconvulsant properties; 5) aripiprazole has anticonvulsant properties; 6) risperidone, in comparison with other APs, maintained its proconvulsant effects after withdrawal for some weeks, more than other compounds, whereas aripiprazole had a proconvulsant rebound effect.

Despite the action of APs on several neurotransmitter receptor subtypes, none of the drugs tested in this animal model showed acute effects on seizures. However, chronic administration of APs is known to alter the regional density of several neurotransmitter receptors in the central nervous system, including those for dopamine, serotonin, acetylcholine, histamine, and glutamate, that may contribute to the observed proconvulsant effects of some antipsychotics [42, 53, 54]. These changes, in particular upregulation of dopamine receptors, have been suggested as the basis for some of the adverse effects that occur with long-term antipsychotic therapy [55]. The effects of APs and their known affinities for several receptor subtypes are listed in Table 2.

Indeed, the proconvulsant effects of clozapine, risperidone, quetiapine, and olanzapine could be explained, in part, via their interactions with serotonergic and/or dopaminergic receptor systems, even though other mechanisms also possessed by such drugs could account for the observed proconvulsant action. Several APs are reported to affect GABAergic neurotransmission; in particular, some of them, including clozapine, inhibit GABA response on the $\mathrm{GABA}_{\mathrm{A}}$ receptor-chloride channel complex. The inhibitory effect of some APs on GABA-induced chloride currents was ranked as follows: clozapine $>$ zotepine $>$ chlorpromazine $>$ olanzapine $>$ risperidone [71]. This rank is in agreement with our results; however, some of the APs used in our study were not previously evaluated. Finally, all tested APs block noradrenergic $\alpha 2$ receptors, which is also known to increase audiogenic seizure susceptibility [72], and, most noticeably, clozapine, risperidone, and olanzapine, which are the most proconvulsant APs of this group, differ from the others by their ability to act as inverse agonist on 5-hydroxytryptamine (HT) 2c receptors, which has been previously suggested to play a role in epilepsy and particularly in audiogenic seizures [73, 74].

The effects of each drug are considered below.

\section{Haloperidol}

Haloperidol, which possesses antagonist activity at D2 dopamine receptors, demonstrated a very modest proconvulsant activity in our model, and this might suggest that dopaminergic neurotransmission at D2 receptors is not involved in the proconvulsant effects observed in GEPR strain after chronic atypical antipsychotic treatment (also supported by the highest proconvulsant effects during clozapine treatment, which, among the APs used, is the one with the lowest affinity for D2 receptors). Furthermore, haloperidol binds with a low affinity to the adrenergic $(\alpha 1$ and $\alpha 2)$ and histaminergic H1 receptors $[75,76]$. We investigated the effects of haloperidol on audiogenic seizure in epileptic rats, demonstrating that this drug did not significantly increase seizure incidence and/or severity (Figs. 1b, 2, 3a). Our data are in agreement with that observed in human therapy where haloperidol is one of the agents with the least seizure-induction activity among antipsychotics [8].

\section{Clozapine}

Clozapine was the AP with the highest significant proconvulsant effect on GEPRs, and these effects persisted for 3-4 weeks during withdrawal in chronically treated rats, suggesting that its effects are long-lasting over its elimination [77]. Clozapine is a multireceptor acting AP; it has antagonistic activity on dopaminergic receptors, with a higher affinity at the $\mathrm{D} 1$ and $\mathrm{D} 4$ receptors than at the $\mathrm{D} 2$ receptors, also binding to the extra-striatal D3 receptors. Clozapine has also antagonistic activity at the 5-HT1A, 5-HT2A, 5-HT2C, and 5-HT3 receptors [75]. Our results are in agreement with previous reports indicating that clozapine is the atypical AP that more frequently is associated with seizures [17], or involving seizures/lowered seizure threshold associated with its use $[78,79]$. The incidence of audiogenic seizures was significantly increased by clozapine chronic treatment in all subgroups of GEPRs (Figs. 1a, b; 2; 3a, b). At odds are the 5-HT2 and/or 5-HT3 antagonistic properties of clozapine, which were indicated to be responsible for its inhibitory effects on audiogenic seizures in ethanol withdrawal syndrome (EWS) in rats [80]. The observed discrepancy between audiogenic seizures in GEPRs and those in EWS rats may be due to differences between the 2 strains and the likely different mechanisms involved in the pathogenesis of ethanol withdrawal-induced audiogenic seizures [81-83]. 
Table 2 Typical and atypical antipsychotic drugs: mechanisms of action and relative affinities to central nervous system neurotransmitter receptors

\begin{tabular}{|c|c|c|c|c|c|c|c|}
\hline Receptor subtypes & Quetiapine (A) & Risperidone (A) & Aripiprazole (A) & Olanzapine (A) & Clozapine (A) & Haloperidol $(\mathrm{T})$ & Ref. \\
\hline $\mathrm{D}_{2}$ & $\begin{array}{l}\text { AT } \\
+\end{array}$ & $\begin{array}{l}\text { AT } \\
+++\end{array}$ & $\begin{array}{l}\text { PA } \\
++++\end{array}$ & $\begin{array}{l}\text { AT } \\
++\end{array}$ & $\begin{array}{l}\text { AT } \\
+\end{array}$ & $\begin{array}{l}\text { AT } \\
+++\end{array}$ & {$[56,57]$} \\
\hline $5-\mathrm{HT}_{1 \mathrm{~A}}$ & $\begin{array}{l}\text { PA } \\
+\end{array}$ & $\begin{array}{l}\mathrm{AT} \\
+\end{array}$ & $\begin{array}{l}\text { PA } \\
+++\end{array}$ & $\begin{array}{l}\text { AT } \\
(*)\end{array}$ & $\begin{array}{l}\text { PA } \\
+\end{array}$ & $\begin{array}{l}\text { AT } \\
(*)\end{array}$ & {$[56,58-61]$} \\
\hline $5-\mathrm{HT}_{2 \mathrm{~A}}$ & $\begin{array}{l}\text { AT } \\
+\end{array}$ & $\begin{array}{l}\text { AT } \\
++++\end{array}$ & $\begin{array}{l}\text { AT } \\
+++\end{array}$ & $\begin{array}{l}\text { AT } \\
+++\end{array}$ & $\begin{array}{l}\text { AT } \\
+++\end{array}$ & $\begin{array}{l}\text { AT } \\
++\end{array}$ & {$[60,62,63]$} \\
\hline $5-\mathrm{HT}_{2 \mathrm{C}}$ & $\begin{array}{l}\text { IA } \\
(*)\end{array}$ & $\begin{array}{l}\text { IA } \\
++\end{array}$ & $\begin{array}{l}\text { PA } \\
++\end{array}$ & $\begin{array}{l}\text { IA } \\
+++\end{array}$ & $\begin{array}{l}\text { IA } \\
++\end{array}$ & $\begin{array}{l}\text { AT } \\
(*)\end{array}$ & {$[58,60,64]$} \\
\hline $5-\mathrm{HT}_{7}$ & $\begin{array}{l}\text { AT } \\
+\end{array}$ & $\begin{array}{l}\text { AT } \\
+++\end{array}$ & $\begin{array}{l}\text { PA } \\
+++\end{array}$ & $\begin{array}{l}\text { AT } \\
+\end{array}$ & $\begin{array}{l}\text { AT } \\
++\end{array}$ & $\begin{array}{l}\text { AT } \\
+\end{array}$ & {$[60,64,65]$} \\
\hline$\alpha_{1 \mathrm{~A}}$ & $\begin{array}{l}\text { AT } \\
++\end{array}$ & $\begin{array}{l}\text { AT } \\
+++\end{array}$ & $\begin{array}{l}\text { AT } \\
++\end{array}$ & $\begin{array}{l}\text { AT } \\
+\end{array}$ & $\begin{array}{l}\text { AT } \\
+++\end{array}$ & $\begin{array}{l}\text { AT } \\
++\end{array}$ & {$[64,66]$} \\
\hline$\alpha_{2 \mathrm{~A}}$ & $\mathrm{AT}^{*}$ & $\begin{array}{l}\text { AT } \\
+\end{array}$ & $\begin{array}{l}\text { AT } \\
++\end{array}$ & $\begin{array}{l}\text { AT } \\
+\end{array}$ & $\begin{array}{l}\text { AT } \\
+\end{array}$ & $\mathrm{AT}^{*}$ & {$[58,66,67]$} \\
\hline$\alpha_{2 \mathrm{~B}}$ & $\begin{array}{l}\text { AT } \\
+\end{array}$ & $\begin{array}{l}\text { AT } \\
+\end{array}$ & $\begin{array}{l}\text { AT } \\
+\end{array}$ & $\begin{array}{l}\text { AT } \\
++\end{array}$ & $\begin{array}{l}\text { AT } \\
++\end{array}$ & $\begin{array}{l}\text { AT } \\
+\end{array}$ & {$[58,66,67]$} \\
\hline$\alpha_{2 \mathrm{C}}$ & $\begin{array}{l}\text { AT } \\
++\end{array}$ & $\begin{array}{l}\text { AT } \\
+++\end{array}$ & $\begin{array}{l}\text { AT } \\
++\end{array}$ & $\begin{array}{l}\text { AT } \\
++\end{array}$ & $\begin{array}{l}\text { AT } \\
++\end{array}$ & $\begin{array}{l}\mathrm{AT} \\
+\end{array}$ & {$[58,66-68]$} \\
\hline $\mathrm{M}_{1}$ & $\begin{array}{l}\text { AT } \\
+\end{array}$ & $\mathrm{AT}^{*}$ & $\mathrm{AT}^{*}$ & $\begin{array}{l}\text { AT } \\
++\end{array}$ & $\begin{array}{l}\text { AT } \\
++\end{array}$ & $\mathrm{AT}^{*}$ & [69] \\
\hline $\mathrm{M}_{3}$ & $\mathrm{AT}^{*}$ & $\mathrm{AT}^{*}$ & $\mathrm{AT}^{*}$ & $\begin{array}{l}\text { AT } \\
+\end{array}$ & $\begin{array}{l}\text { AT } \\
++\end{array}$ & $\mathrm{AT}^{*}$ & [69] \\
\hline $\mathrm{H}_{1}$ & $\begin{array}{l}\text { AT } \\
++\end{array}$ & $\begin{array}{l}\text { AT } \\
++\end{array}$ & $\begin{array}{l}\text { AT } \\
++\end{array}$ & $\begin{array}{l}\text { AT } \\
+++\end{array}$ & $\begin{array}{l}\text { AT } \\
+++\end{array}$ & $\mathrm{AT}^{*}$ & {$[70]$} \\
\hline
\end{tabular}

$\mathrm{A}=$ atypical antipsychotic drug; $\mathrm{T}=$ typical antipsychotic drug; 5 -HT $=$ serotonin receptors; $\mathrm{D}=$ dopamine receptors; $\mathrm{AT}=$ antagonist; $\mathrm{PA}=$ partial agonist; IA = inverse agonist; $\alpha=$ noradrenaline receptors; $\mathrm{M}=$ acetylcholine receptors; $\mathrm{H}=$ histamine receptors; $;+=$ weak binding affinity $(100 \mathrm{nM}<$ $\mathrm{Ki}<1000 \mathrm{nM}) ;++=$ moderate binding affinity $(10 \mathrm{nM}<\mathrm{Ki}<100 \mathrm{nM}) ;+++=$ strong binding affinity $(1 \mathrm{nM}<\mathrm{Ki}<10 \mathrm{nM})$; ++++= very strong binding affinity $(\mathrm{Ki}<1 \mathrm{nM})$

*Negligible binding affinity $(\mathrm{Ki}>1000 \mathrm{nM})$

Serotonergic transmission has been suggested to be involved in seizures in GEPRs; in particular, a previous study showed that the severity of audiogenic seizures was decreased in a dose-dependent fashion by fluoxetine, a selective serotonin reuptake inhibitor [84].

Clozapine displays strong affinity for several dopamine receptor subtypes and it has been proposed that such changes have selectivity for mesolimbic dopamine receptors, which might account for its proconvulsant effects [41]. However, clozapine is an antagonist with a high affinity at $\alpha 2-$ adrenoceptors $[66,85]$; this mechanism may also be responsible for proconvulsant effects on audiogenic seizures in GEPRs, as previously described for other compounds acting on $\alpha 2$-adrenoceptors [86].

\section{Risperidone}

Risperidone has a high affinity for the 5-HT2A receptors, with a D2 receptor affinity similar to most typical APs. Compared with typical APs, it also binds with a lower affinity at the adrenergic $(\alpha 1$ and $\alpha 2)$ and $H 1$ histaminergic receptors [75, 76]. We found that risperidone increases the incidence and the severity of the audiogenic seizures (Figs. 1a, b; 2; 3a, c). The latter data are partially in contrast with that observed in human therapy where risperidone is an agent with the lowest seizure induction activity among APs [8]. However, a previous clinical study indicated that risperidone overdose is able to induce seizures [87].

\section{Quetiapine and Ketotifen Fumarate}

Quetiapine, another atypical AP, has similar receptor-binding properties to clozapine, but with relatively lower affinity for all receptors and nearly no affinity for muscarinic and 5-HT2c receptors, and a higher relative affinity for $\mathrm{H} 1$ and $\alpha 1$ adrenergic receptors [76]. Quetiapine also increased the severity of audiogenic seizures, but we observed that such effects disappeared within 2 weeks of withdrawal (Figs. 1b; 3a; 5a, b). This proconvulsant effect observed in GEPR strain was opposite to the anticonvulsant properties in EWS rats reported by Celikyurt et al. [20].

Considering that the main difference between quetiapine and the other APs studied is represented by its strong relative anti-H1 activity and that $\mathrm{H} 1$ antagonists are known to be proconvulsant $[88,89]$; we evaluated the effects of ketotifen fumarate in order to establish whether a link between quetiapine effects and such a mechanism of action would be responsible to the observed lower proconvulsant effects 
compared with other APs. We found that ketotifen fumarate was also proconvulsant; therefore, we can conclude that other mechanisms are involved in the lower proconvulsant activity of quetiapine. Furthermore, the proconvulsant effect of ketotifen fumarate due to $\mathrm{H} 1$ receptor block also supports the idea that such a mechanism can contribute to the proconvulsant effects of all APs tested.

\section{Aripiprazole}

Aripiprazole was the only AP with anticonvulsant properties in this genetic model of audiogenic epilepsy (Figs. 1b; 3d; 4). Aripiprazole is a partial D2 agonist and an antagonist/partial agonist of 5-HT2 receptors [90]. Aripiprazole has only $0.1 \%$ seizure-inducing potential, much lower than other APs [91, 92]. The effects of aripiprazole were observed at highest doses characterized by occupancy of $>90 \%$ of D2 receptors [90]. The effects of aripiprazole might be owing to its partial agonistic effects on D2 and 5-HT2c receptors.

\section{Olanzapine}

We have shown worsened audiogenic seizures during olanzapine chronic treatment, and such effects were observed for 3-4 weeks, even after withdrawal (Figs. 1a, b; 2; 3a,b).

Olanzapine has a high binding ratio for 5-HT2A, D2, D4, and $\mathrm{H} 1$ receptors. Similarly to clozapine, olanzapine is an antagonist of dopamine (D1-D4) and 5-HT2A receptors [93]. As doses of olanzapine $>2 \mathrm{mg} / \mathrm{kg}$ caused sedative effects in rats [43], doses of 0.13 and $0.66 \mathrm{mg} / \mathrm{kg}$ of olanzapine were used in the present study. We observed that olanzapine enhances the severity of audiogenic seizures, and this effect may be explained by its serotonin 5-HT2, dopamine D2, and histamine $\mathrm{H} 1$ receptor antagonistic activity. Our results are in agreement with other previous reports in which olanzapine treatment was associated with seizures or lowered seizure threshold $[9,94,95]$. The difference observed in comparison with clozapine might be due to the dose used and higher doses might have similar effects to those observed during clozapine treatment.

\section{Conclusions}

In summary, these results confirm that APs might have potential in increasing the severity of audiogenic seizures but, more interestingly, that aripiprazole alone exerts anticonvulsant effects. The low incidence of seizures related to the use of aripiprazole in patients, together with our results, seems promising. However, further studies in other animal models of epilepsy are required to confirm this action.
APs showed proconvulsant effects only in seizure-prone animals and after 5 days or more of treatment. This might indicate that: 1) APs may need an already established predisposition toward hyperexcitability in order to promote seizures, even though it cannot be excluded that seizure thresholds for other seizures types might have been lowered and not observed; 2) acute treatment seems to have no effects and therefore it is very likely that most of our results might be due to plastic changes occurring during longer periods of treatment, which are, in any case, reversible when stopping treatment. In conclusion, the use of APs in patients, and particularly in patients with epilepsy, should be strictly monitored for the occurrence of seizures; however, attention should also be paid to the withdrawal of APs. Further studies will determine whether aripiprazole really has potential as an anticonvulsant drug and be clinically relevant for patients with epilepsy with psychiatric comorbidities such as psychosis and mood disorders.

Acknowledgments The European Commission, the European Social Fund, and the Calabria Region Government are gratefully acknowledged for their support with student grants. All such organizations only provided economical support without interfering with the content of the present article.

Required Author Forms Disclosure forms provided by the authors are available with the online version of this article.

Disclosure/conflict of interest None of the authors has any conflict of interest to disclose in relation to this work. We confirm that we have read the Journal's position on issues involved in ethical publication and affirm that this report is consistent with those guidelines.

\section{References}

1. Marks RC, Luchins DJ. Antipsychotic medications and seizures. Psychiatr Med 1991;9:37-52.

2. Trifiro G, Spina E. Age-related changes in pharmacodynamics: focus on drugs acting on central nervous and cardiovascular systems. Curr Drug Metab 2011;12:611-620.

3. Arana GW. An overview of side effects caused by typical antipsychotics. J Clin Psychiatry 2000;61(Suppl. 8):5-11.

4. Gareri P, De Fazio P, Stilo M, Ferreri G, De Sarro G. Conventional and atypical antipsychotics in the elderly: A review. Clin Drug Investig 2003;23:287-322.

5. Gareri P, De Fazio P, De Fazio S, et al. Adverse effects of atypical antipsychotics in the elderly: A review. Drugs Aging 2006;23:937-956.

6. Gareri P, De Fazio P, Russo E, Marigliano N, De Fazio S, De Sarro G. The safety of clozapine in the elderly. Expert Opin Drug Saf 2008;7: 525-538.

7. Alldredge BK. Seizure risk associated with psychotropic drugs: clinical and pharmacokinetic considerations. Neurology 1999;53: S68-75.

8. Lertxundi U, Hernandez R, Medrano J, Domingo-Echaburu S, Garcia M, Aguirre C. Antipsychotics and seizures: higher risk with atypicals? Seizure 2013;22:141-143.

9. Hedges D, Jeppson K, Whitehead P. Antipsychotic medication and seizures: a review. Drugs Today (Barc) 2003;39:551-557. 
10. Kanner AM. Can neurobiological pathogenic mechanisms of depression facilitate the development of seizure disorders? Lancet Neurol 2012;11:1093-1102.

11. Kanner AM, Schachter SC, Barry JJ, et al. Depression and epilepsy: epidemiologic and neurobiologic perspectives that may explain their high comorbid occurrence. Epilepsy Behav 2012;24:156-168.

12. Kanner AM. Is depression a risk factor of worse response to therapy in epilepsy? Epilepsy Curr 2011;11:50-51.

13. Kanner AM. Depression and epilepsy: A bidirectional relation? Epilepsia 2011;52(Suppl. 1):21-27.

14. Hesdorffer DC, Hauser WA, Olafsson E, Ludvigsson P, Kjartansson O. Depression and suicide attempt as risk factors for incident unprovoked seizures. Ann Neurol 2006;59:35-41.

15. Lomas J, Boardman RH, Markowe M. Complications of chlorpromazine therapy in 800 mental-hospital patients. Lancet 1955;268:11441147.

16. Casey DE. The relationship of pharmacology to side effects. J Clin Psychiatry 1997;58(Suppl. 10):55-62.

17. Kumlien E, Lundberg PO. Seizure risk associated with neuroactive drugs: data from the WHO adverse drug reactions database. Seizure 2010;19:69-73.

18. Pisani F, Oteri G, Costa C, Di Raimondo G, Di Perri R. Effects of psychotropic drugs on seizure threshold. Drug Saf 2002;25:91-110.

19. Stevens JR, Denney D, Szot P. Kindling with clozapine: behavioral and molecular consequences. Epilepsy Res 1996;26:295-304.

20. Celikyurt IK, Kayir H, Ulak G, Erden FB, Ulusoy GK, Uzbay TI. Effects of risperidone, quetiapine and ziprasidone on ethanol withdrawal syndrome in rats. Prog Neuropsychopharmacol Biol Psychiatry 2011;35:528-536.

21. Kayir H, Uzbay T. Effects of clozapine on ethanol withdrawal syndrome in rats. Alcohol Alcohol 2008;43:619-625.

22. Unsalan N, Saglam E, Kayir H, Uzbay T. Effects of olanzapine on ethanol withdrawal syndrome in rats. Eur J Pharmacol 2008;579:208214.

23. Russo E, Citraro R, Davoli A, Gallelli L, Di Paola ED, De Sarro G. Ameliorating effects of aripiprazole on cognitive functions and depressive-like behavior in a genetic rat model of absence epilepsy and mild-depression comorbidity. Neuropharmacology 2013;64:371379.

24. Faingold CL. Neuronal networks in the genetically epilepsy-prone rat. Adv Neurol 1999;79:311-321.

25. De Sarro G, De Sarro A, Ammendola D, Patel S. Lack of development of tolerance to anticonvulsant effects of two excitatory amino acid antagonists, CGP [corrected] 37849 and CGP 39551 in genetically epilepsy-prone rats. Brain Res 1996;734:91-97.

26. De Sarro A, Grasso S, Zappala M, Nava F, De Sarro G. Convulsant effects of some xanthine derivatives in genetically epilepsy-prone rats. Naunyn Schmiedebergs Arch Pharmacol 1997;356:48-55.

27. Dailey JW, Reigel CE, Mishra PK, Jobe PC. Neurobiology of seizure predisposition in the genetically epilepsy-prone rat. Epilepsy Res 1989;3:3-17.

28. Mishra PK, Dailey JW, Reigel CE, Jobe PC. Audiogenic convulsions in moderate seizure genetically epilepsy-prone rats (GEPR-3s). Epilepsy Res 1989;3:191-198.

29. Reigel CE, Jobe PC, Dailey JW, Savage DD. Ontogeny of soundinduced seizures in the genetically epilepsy-prone rat. Epilepsy Res 1989;4:63-71.

30. Reigel CE, Dailey JW, Jobe PC. The genetically epilepsy-prone rat: an overview of seizure-prone characteristics and responsiveness to anticonvulsant drugs. Life Sci 1986;39:763-774.

31. Dailey JW, Jobe PC. Anticonvulsant drugs and the genetically epilepsy-prone rat. Fed Proc 1985;44:2640-2644.

32. De Sarro GB, De Sarro A. Anticonvulsant properties of noncompetitive antagonists of the N-methyl-D-aspartate receptor in genetically epilepsy-prone rats: comparison with CPPene. Neuropharmacology 1993;32:51-58.
33. De Sarro A, De Sarro GB. Responsiveness of genetically epilepsyprone rats to aminophylline-induced seizures and interactions with quinolones. Neuropharmacology 1991;30:169-176.

34. Jobe PC, Picchioni AL, Chin L. Role of brain norepinephrine in audiogenic seizure in the rat. J Pharmacol Exp Ther 1973;184:1-10.

35. Jobe PC, Mishra PK, Ludvig N, Dailey JW. Scope and contribution of genetic models to an understanding of the epilepsies. Crit Rev Neurobiol 1991;6:183-220.

36. Citraro R, Scicchitano F, De Fazio S, et al. Preclinical activity profile of alpha-lactoalbumin, a whey protein rich in tryptophan, in rodent models of seizures and epilepsy. Epilepsy Res 2011;95:60-69.

37. Mishra PK, Dailey JW, Reigel CE, Jobe PC. Brain norepinephrine and convulsions in the genetically epilepsy-prone rat: Sex-dependent responses to Ro 4-1284 treatment. Life Sci 1988;42:1131-1137.

38. Jobe PC, Dailey JW, Reigel CE. Noradrenergic and serotonergic determinants of seizure susceptibility and severity in genetically epilepsy-prone rats. Life Sci 1986;39:775-782.

39. Gareri P, Condorelli D, Belluardo N, et al. Anticonvulsant effects of carbenoxolone in genetically epilepsy prone rats (GEPRs). Neuropharmacology 2004;47:1205-1216.

40. Russo E, Citraro R, Scicchitano F, et al. Effects of early long-term treatment with antiepileptic drugs on development of seizures and depressive-like behavior in a rat genetic absence epilepsy model. Epilepsia 2011;52:1341-1350.

41. Minabe Y, Watanabe K, Nishimura T, Ashby CR, Jr. Acute and chronic administration of clozapine produces greater proconvulsant actions than haloperidol on focal hippocampal seizures in freely moving rats. Synapse 1998;29:272-278.

42. Tarazi FI, Baldessarini RJ, Kula NS, Zhang K. Long-term effects of olanzapine, risperidone, and quetiapine on ionotropic glutamate receptor types: implications for antipsychotic drug treatment. J Pharmacol Exp Ther 2003;306:1145-1151.

43. Ortega-Alvaro A, Gibert-Rahola J, Mico JA. Influence of chronic treatment with olanzapine, clozapine and scopolamine on performance of a learned 8-arm radial maze task in rats. Prog Neuropsychopharmacol Biol Psychiatry 2006;30:104-111.

44. Russo E, Citraro R, Scicchitano F, et al. Comparison of the antiepileptogenic effects of an early long-term treatment with ethosuximide or levetiracetam in a genetic animal model of absence epilepsy. Epilepsia 2010;51:1560-1569.

45. Russo E, Citraro R, Scicchitano F, et al. Vigabatrin has antiepileptogenic and antidepressant effects in an animal model of epilepsy and depression comorbidity. Behav Brain Res 2011;225: 373-376.

46. Russo E, Citraro R, Donato G, et al. mTOR inhibition modulates epileptogenesis, seizures and depressive behavior in a genetic rat model of absence epilepsy. Neuropharmacology 2013;69:25-36.

47. Citraro R, Chimirri S, Aiello R, et al. Protective effects of some statins on epileptogenesis and depressive-like behavior in WAG/Rij rats, a genetic animal model of absence epilepsy. Epilepsia 2014;55: 1284-1291.

48. Jobe PC, Dailey JW. Neurobiology of seizure predisposition in the genetically epilepsy prone rat. Proc West Pharmacol Soc 1991;34: 223-225.

49. Russo E, Donato di Paola E, Gareri P, et al. Pharmacodynamic potentiation of antiepileptic drugs' effects by some HMG-CoA reductase inhibitors against audiogenic seizures in DBA/2 mice. Pharmacol Res 2013;70:1-12.

50. De Sarro G, Trimarchi GR, Federico F, De Sarro A. Anticonvulsant activity of some calcium antagonists in genetically epilepsy prone rats. Epilepsy Res Suppl 1991;3:49-55.

51. Russo E, Citraro R, De Fazio S, Torcasio G, De Sarro G, Di Paola ED. Effects of ethanol on the development of genetically determined epilepsies in rats. Int J Dev Neurosci 2008;26:739-744.

52. Gareri P, Cotroneo A, Lacava R, et al. Comparison of the efficacy of new and conventional antipsychotic drugs in the treatment of 
behavioral and psychological symptoms of dementia (BPSD). Arch Gerontol Geriatr Suppl 2004:207-215.

53. Tarazi FI, Zhang K, Baldessarini RJ. Long-term effects of olanzapine, risperidone, and quetiapine on serotonin $1 \mathrm{~A}, 2 \mathrm{~A}$ and $2 \mathrm{C}$ receptors in rat forebrain regions. Psychopharmacology (Berl) 2002;161:263270.

54. Lee JW, Crismon ML, Dorson PG. Seizure associated with olanzapine. Ann Pharmacother 1999;33:554-556.

55. Tarazi FI, Florijn WJ, Creese I. Differential regulation of dopamine receptors after chronic typical and atypical antipsychotic drug treatment. Neuroscience 1997;78:985-996.

56. Tanahashi S, Yamamura S, Nakagawa M, Motomura E, Okada M. Dopamine D2 and serotonin 5-HT1A receptors mediate the actions of aripiprazole in mesocortical and mesoaccumbens transmission. Neuropharmacology 2012;62:765-774.

57. Strange PG. Antipsychotic drugs: Importance of dopamine receptors for mechanisms of therapeutic actions and side effects. Pharmacol Rev 2001;53:119-133.

58. Kroeze WK, Hufeisen SJ, Popadak BA, et al. H1-histamine receptor affinity predicts short-term weight gain for typical and atypical antipsychotic drugs. Neuropsychopharmacology 2003;28:519-526.

59. McIntyre RS, Soczynska JK, Woldeyohannes HO, Alsuwaidan M, Konarski JZ. A preclinical and clinical rationale for quetiapine in mood syndromes. Expert Opin Pharmacother 2007;8:1211-1219.

60. Meltzer HY, Massey BW. The role of serotonin receptors in the action of atypical antipsychotic drugs. Curr Opin Pharmacol 2011;11:59-67.

61. Lerond J, Lothe A, Ryvlin P, et al. Effects of aripiprazole, risperidone, and olanzapine on 5-HT1A receptors in patients with schizophrenia. J Clin Psychopharmacol 2013;33:84-89.

62. Love RC, Nelson MW. Pharmacology and clinical experience with risperidone. Expert Opin Pharmacother 2000;1:1441-1453.

63. Yadav PN, Kroeze WK, Farrell MS, Roth BL. Antagonist functional selectivity: 5-HT2A serotonin receptor antagonists differentially regulate 5-HT2A receptor protein level in vivo. J Pharmacol Exp Ther 2011;339:99-105.

64. Shapiro DA, Renock S, Arrington E, et al. Aripiprazole, a novel atypical antipsychotic drug with a unique and robust pharmacology. Neuropsychopharmacology 2003;28:1400-1411.

65. Teitler M, Toohey N, Knight JA, Klein MT, Smith C. Clozapine and other competitive antagonists reactivate risperidone-inactivated h5HT7 receptors: radioligand binding and functional evidence for GPCR homodimer protomer interactions. Psychopharmacology (Berl) 2010;212:687-697.

66. Svensson TH. Alpha-adrenoceptor modulation hypothesis of antipsychotic atypicality. Prog Neuropsychopharmacol Biol Psychiatry 2003;27:1145-1158.

67. Brosda J, Jantschak F, Pertz HH. alpha2-Adrenoceptors are targets for antipsychotic drugs. Psychopharmacology (Berl) 2014;231:801812.

68. Kalkman HO, Loetscher E. alpha2C-Adrenoceptor blockade by clozapine and other antipsychotic drugs. Eur J Pharmacol 2003;462:3340.

69. Bymaster FP, Felder CC, Tzavara E, Nomikos GG, Calligaro DO, McKinzie DL. Muscarinic mechanisms of antipsychotic atypicality. Prog Neuropsychopharmacol Biol Psychiatry 2003;27:1125-1143.

70. He M, Deng C, Huang XF. The role of hypothalamic H1 receptor antagonism in antipsychotic-induced weight gain. CNS Drugs 2013;27:423-434

71. Yokota K, Tatebayashi H, Matsuo T, et al. The effects of neuroleptics on the GABA-induced $\mathrm{Cl}$ - current in rat dorsal root ganglion neurons: differences between some neuroleptics. Br J Pharmacol 2002;135: $1547-1555$.

72. Yan QS, Dailey JW, Steenbergen JL, Jobe PC. Anticonvulsant effect of enhancement of noradrenergic transmission in the superior colliculus in genetically epilepsy-prone rats (GEPRs): a microinjection study. Brain Res 1998;780:199-209.
73. Brennan TJ, Seeley WW, Kilgard M, Schreiner CE, Tecott LH. Sound-induced seizures in serotonin 5-HT2c receptor mutant mice. Nat Genet 1997;16:387-390.

74. Applegate CD, Tecott LH. Global increases in seizure susceptibility in mice lacking 5-HT2C receptors: a behavioral analysis. Exp Neurol 1998; 154:522-530.

75. Richtand NM, Welge JA, Logue AD, Keck PE, Jr., Strakowski SM, McNamara RK. Dopamine and serotonin receptor binding and antipsychotic efficacy. Neuropsychopharmacology 2007;32:1715-1726.

76. Uzbay IT. [New pharmacological approaches to the treatment of schizophrenia]. Turk Psikiyatri Derg 2009;20:175-182 (in Turkish).

77. Baldessarini RJ, Centorrino F, Flood JG, Volpicelli SA, HustonLyons D, Cohen BM. Tissue concentrations of clozapine and its metabolites in the rat. Neuropsychopharmacology 1993;9:117-124.

78. Langosch JM, Trimble MR. Epilepsy, psychosis and clozapine. Hum Psychopharmacol 2002;17:115-119.

79. White DM, Van Cott AC. Clozapine (Clozaril), seizures, and EEG abnormalities. Am J Electroneurodiagnostic Technol 2007;47:190-197.

80. Uzbay TI. Atypical antipsychotic drugs and ethanol withdrawal syndrome: a review. Alcohol Alcohol 2012;47:33-41.

81. Trzaskowska E, Krzascik P, Staniszewska A, Pucilowski O, Kostowski W. On the relative importance of D-1 vs. D-2 dopaminergic receptors in the control of audiogenic seizures in ethanol withdrawn rats. Drug Alcohol Depend 1989;24:265-267.

82. Uzbay IT, Usanmaz SE, Tapanyigit EE, Aynacioglu S, Akarsu ES. Dopaminergic and serotonergic alterations in the rat brain during ethanol withdrawal: association with behavioral signs. Drug Alcohol Depend 1998;53:39-47.

83. Yu L, Fisher H, Wagner GC. Monoaminergic changes associated with audiogenic seizures in ethanol-dependent rats. Prog Neuropsychopharmacol Biol Psychiatry 2000;24:1379-1392.

84. Yan QS, Jobe PC, Cheong JH, Ko KH, Dailey JW. Role of serotonin in the anticonvulsant effect of fluoxetine in genetically epilepsy-prone rats. Naunyn Schmiedebergs Arch Pharmacol 1994;350:149-152.

85. Kalkman HO, Neumann V, Hoyer D, Tricklebank MD. The role of alpha2-adrenoceptor antagonism in the anti-cataleptic properties of the atypical neuroleptic agent, clozapine, in the rat. Br J Pharmacol 1998; 124:1550-1556.

86. Yan QS, Jobe PC, Dailey JW. Noradrenergic mechanisms for the anticonvulsant effects of desipramine and yohimbine in genetically epilepsyprone rats: studies with microdialysis. Brain Res 1993;610:24-31.

87. Acri AA, Henretig FM. Effects of risperidone in overdose. Am J Emerg Med 1998;16:498-501.

88. Gerald MC, Richter NA. Studies on the effects of histaminergic agents on seizure susceptibility in mice. Psychopharmacologia 1976; $46: 277-282$.

89. Sturman G, Freeman P, Quinn L. Histamine H1-antagonists potentiate seizures in the EL (epilepsy-like) mouse model of temporal lobe epilepsy. Inflamm Res 2001;50(Suppl.) 2:S80-S81.

90. Natesan S, Reckless GE, Nobrega JN, Fletcher PJ, Kapur S. Dissociation between in vivo occupancy and functional antagonism of dopamine D2 receptors: comparing aripiprazole to other antipsychotics in animal models. Neuropsychopharmacology 2006;31: 1854-1863.

91. Tsai JF. Aripiprazole-associated seizure. J Clin Psychiatry 2006;67: 995-996.

92. Lin KH, Chen YJ, Lin YT, et al. Serious generalized tonic-clonic seizures induced by aripiprazole. Prog Neuropsychopharmacol Biol Psychiatry 2010;34:231-232.

93. Meltzer HY. Update on typical and atypical antipsychotic drugs. Annu Rev Med 2013;64:393-406.

94. Woolley J, Smith S. Lowered seizure threshold on olanzapine. Br J Psychiatry 2001;178:85-86.

95. Camacho A, Garcia-Navarro M, Martinez B, Villarejo A, Pomares E. Olanzapine-induced myoclonic status. Clin Neuropharmacol 2005;28:145-147. 